\title{
A direct analysis of Lithuanian phrasal comparatives
}

\section{ELENA VAIKŠNORAITĖ [D}

\begin{abstract}
Phrasal comparatives like John runs faster than Tom can be derived via two routes: i) Direct Analyses assume that the argument of than is a DP; ii) Reduced Clause Analyses assume that the than-phrase is a clause that is subject to some reduction operation (John runs faster than Tom runs). Based on standard diagnostics used to adjudicate between the two analyses, I argue that Lithuanian phrasal comparatives are best analyzed as directly licensed. I develop a direct analysis of Lithuanian phrasal comparatives that captures the empirical generalizations previously discussed in the literature and a new empirical generalization identified in this paper. This proposal is contra Grinsell (2012), who argued that Lithuanian phrasal comparatives are underlyingly clausal based on data that are suggested to show island sensitivity. I argue against Grinsell's (2012) reduced clause analysis by showing that the island sensitivity of Lithuanian phrasal comparatives can be successfully captured in a direct analysis.
\end{abstract}

\section{]u[ubiquity press}

RESEARCH

CORRESPONDING AUTHOR:

\section{Elena Vaikšnoraitè}

The Ohio State University/ University of Stuttgart, Stuttgart, DE

elena.vaiksnoraite@ling. unistuttgart.de

\section{KEYWORDS:}

phrasal comparatives; direct analysis; island effects; economy; parasitic scope

TO CITE THIS ARTICLE:

Vaikšnoraitè, Elena. 2021. A direct analysis of Lithuanian phrasal comparatives. Glossa: a journal of general linguistics 6(1): 65. 1-18. DOI: https:// doi.org/10.5334/gjgl.935 


\section{Introduction}

Phrasal comparatives are comparatives in which the standard of comparison superficially is a DP. ${ }^{1}$ In the Lithuanian example in (1), the standard of comparison is the accusative case-marked DP Toma 'Tom', which contrasts with the nominative case-marked associate Jonas 'John'. In phrasal comparatives, the standard marker is $u \check{z}$ 'than'.

$$
\begin{array}{ll}
\text { Jonas aušt-esn-is už } & \text { Tomą. } \\
\text { John.NOM tall-ER-NOM than.PHRASAL } & \text { Tom.ACC } \\
\text { 'John is taller than Tom.' } &
\end{array}
$$

Lithuanian also has a clausal comparative, a comparative in which the standard of comparison is a clause. In (2), the standard of comparison is a clause that can optionally contain the complementizer kad 'that'. In clausal comparatives, the standard marker is negu 'than'.

$$
\begin{aligned}
& \text { Jonas auštesnis negu } \quad \text { (kad) Tomas. } \\
& \text { John.NOM taller.NOM than.CLAUSAL that Tom.NOM } \\
& \text { 'John is taller than Tom.' }
\end{aligned}
$$

Clausal comparatives are traditionally analyzed as derived from clausal sources, i.e. the standard of comparison is a clause that is subject to a reduction operation (e.g. Lechner 2001; Merchant 2009, among others).

Regarding the syntax of phrasal comparatives, there are two classes of analyses, which differ in the assumed syntactic size of the standard of comparison: reduced clause analyses (RCAs) and direct analyses (DAs). Under RCAs, phrasal comparatives are bi-clausal. The standard of comparison is a clause that is subject to some reduction operation(s) (e.g. Lechner 2001; 2004; Pancheva 2006; 2009; Merchant 2009, among others). In (3), the standard of comparison undergoes ellipsis (the elided material is indicated by the angled brackets) and the only phrase that survives ellipsis is the remnant, Toma 'Tom'. The remnant and Jonas 'John' occupy parallel positions in separate clauses, i.e. they are subjects in their respective clauses.

$$
\begin{aligned}
& \text { Jonas auštesnis už } \quad \text { Tomą < aukštas }>\text {. } \\
& \text { John.NOM taller.NOM than.PHRASAL Tom.ACC tall.NOM } \\
& \text { 'John is taller than Tom.' }
\end{aligned}
$$

Under DAs, the standard of comparison is a DP (e.g. Hankamer 1973; Bhatt \& Takahashi 2007; 2007, among others). Consequently, the standard of comparison is in the same clause as the associate.

It has been accepted in the literature that both RCAs and DAs are attested cross-linguistically. The big question is how to decide which strategy is employed in a particular language.

Given that RCAs and DAs make different assumptions regarding the size of the standard of comparison, a number of diagnostics that are sensitive to clausal boundaries have been proposed to adjudicate between the two analyses. RCAs and DAs make different predictions with respect to i) case-marking on the standard of comparison; ii) binding of pronouns and anaphors; iii) whether only a single phrase can follow the standard marker (e.g. Hankamer 1973; Merchant 2009; Bhatt \& Takahashi 2011, among others). I will now discuss how Lithuanian phrasal comparatives fare with respect to the standard diagnostics.

Anaphors (reflexive pronouns) must be locally bound, i.e. they need to have an antecedent in the same clause. Free pronouns, on the other hand, must be locally free, i.e. their antecedent cannot be in the same clause. Consequently, whether a phrase can serve as an antecedent to a (reflexive) pronoun in the standard of comparison can inform us as to whether phrasal comparatives are mono-clausal (as predicted by DAs) or bi-clausal (as predicted by RCAs).

Lithuanian has a strictly clause-bound reflexive anaphor save 'self', which can be inflected for case. The anaphor shows subject orientation as shown in (4), i.e. it can only be bound by a subject in the same clause.

1 In this paper, DP is used as a notational device. I do not take a stand on whether nominal phrases in Lithuanian, an article-less language, are DPs or NPs; see Gillon \& Armoskaite 2015 for a discussion of the nominal phrase structure in Lithuanian. 
Jonas $_{i} \quad$ pristatè $\quad$ Tomui $_{j} \quad$ savo $_{j^{* * j} j}$ brolį.

John.NOM introduce.PST.3 Tom.DAT self.GEN brother.ACC

'John introduced his brother to Tom.'

In phrasal comparatives, the anaphor savo 'self' can be bound by the subject associate, as shown in (5a). In the Lithuanian clausal comparatives, the anaphor savo 'self' cannot be used as shown in (5b). The data in (5) thus shows that the associate Jonas 'John' and the possessive anaphor savo 'self' are in the same clause in phrasal comparatives. This binding pattern is predicted by DAs but not RCAs.
a. Jonas ${ }_{i}$ bėga greičiau už savo $_{i}$ brolị. 'John runs faster than his brother.' John.NOM run.PRS.3 faster than.PHRASAL self.GEN brother.ACC
b. *Jonas ${ }_{i}$ bejga greičiau negu savo $_{i}$ brolis. John.NOM run.PRS.3 faster than.CLAUSAL self.GEN brother.NOM 'John runs faster than his brother.'

Free possessive pronouns in Lithuanian show anti-subject orientation within the same clause. In the Lithuanian example in (6), the possessive pronoun jo 'his' can be co-referential with the indirect object Tomas 'Tom' but not with the subject Jonas 'John'.
Jonas $_{i} \quad$ pristatè
Tomui $_{\mathrm{j}} \mathrm{jo}_{*_{i / j}} \quad$ brolį.
John.NOM introduce.PST.3 Tom.DAT he.GEN brother.ACC
'John introduced Tom to his brother.'

In the phrasal comparative in (7a), the pronominal possessor jo 'his' cannot be coreferential with the subject Jonas 'John'. Therefore it follows that that the associate Jonas 'John' and jo 'his' are in the same clause as predicted by DAs but not RCAs. In the clausal comparative in (7b), on the other hand, jo 'his' is ambiguous between referring to the subject of the clause and some contextually salient individual, which means that the associate Jonas 'John' and jo 'his' are in separate clauses.
a. Jonas $_{i}$ bèga greičiau už jo ${ }_{*_{i} / j}$ brolị.
John.NOM run.PRS.3 faster than.PHRASAL self.GEN brother.ACC
'John runs faster than his brother.'
b. Jonas ${ }_{\mathrm{i}}$ bėga greičiau negu $\mathrm{jo}_{i / j}$ brolis.
John.NOM run.PRS.3 faster than.CLAUSAL self.GEN brother.NOM
'John runs faster than his brother.'

The second diagnostic is case-marking on the standard of comparison. Under RCAs, the standard of comparison occupies a position that is parallel to the one occupied by the associate. The case-marking on the standard thus depends on its structural position. Under DAs, on the other hand, case is assigned locally by the preposition. In Lithuanian, the standard of comparison is invariably accusative case-marked, even when the standard contrasts with the nominative casemarked subject as shown in (8).

$$
\begin{aligned}
& \text { Jonas auštesnis už } \quad \text { Tomą /*Tomas. } \\
& \text { John.NOM taller.NOM than.PHRASAL Tom.ACC / Tom.NOM } \\
& \text { 'John is taller than Tom.' }
\end{aligned}
$$

This case-marking pattern contrasts with German, a language in which phrasal comparatives have been analyzed as underlyingly clausal (Lechner 2001; 2004). In the phrasal comparative in (9), the first person singular pronoun bears either nominative case (ich) in (9a) where it is the subject of the elided clause or accusative case (mich) in (9b) where it is the object of the elided clause.

$$
\begin{aligned}
& \text { German } \\
& \text { a. Er mag dich mehr als ich. } \\
& \text { he.NOM like.PRS.3.sG you.ACC more than I.NOM } \\
& \text { 'He likes you more than I (like you).' }
\end{aligned}
$$


b. Er mag dich mehr als mich.

he.NOM like.PRS.3.SG you.ACC more than I.ACC

'He likes you more than (he likes) me.'

Case invariability in Lithuanian is predicted under a direct analysis: the standard marker $u \check{z}$ 'than' is a preposition and assigns case to its argument. In Lithuanian, prepositions select for a DP argument and assign case. In (3), $u \check{z}$ 'for' is a preposition (homophonous with the standard marker $u \check{z}$ 'than') that assigns accusative case to its DP argument.

$$
\begin{aligned}
& \text { Jonas balsavo už Grybauskaitę. } \\
& \text { John.NOM vote.PST.3 for Grybauskaite.ACC } \\
& \text { 'John voted for Grybauskaite.' }
\end{aligned}
$$

Lastly, RCAs and DAs make different predictions with respect to what can follow the standard marker. Under DAs, the standard of comparison can only be a single phrase, since prepositions take only one argument. Under RCAs, more than one phrase can survive ellipsis, i.e. there can be multiple remnants.

Japanese yori-comparatives allow multiple remnants as shown in (11) and they have received a reduced clause analysis (Bhatt \& Takahashi 2011). ${ }^{2}$

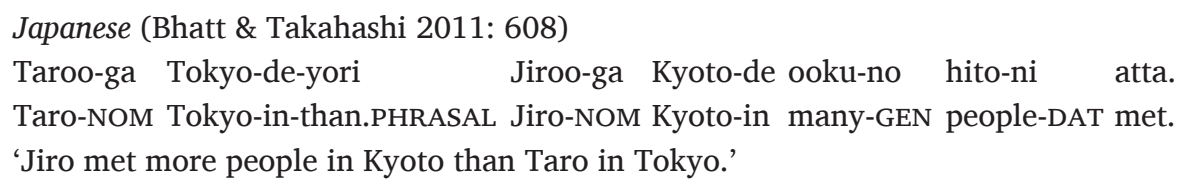

In English, syntactic categories other than DPs can function as the standard of comparison as shown in (12), where the standard is an adverb.

$$
\text { John read more books today than yesterday. }
$$

Lithuanian phrasal comparatives allow only a single argument to follow the standard marker $u$ ž 'than' as shown in (13a). Furthermore, the standard of comparison must be a DP as shown in (13b), where the standard is the adverb vakar 'yesterday'. ${ }^{3}$

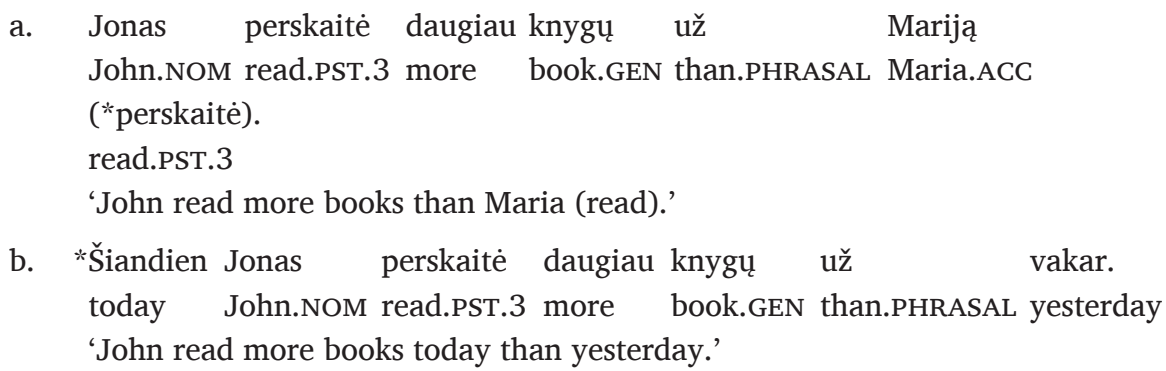

Since prepositions take only a single DP argument in Lithuanian, this empirical generalization is predicted by DAs but not RCAs.

In summary, the following generalizations about Lithuanian phrasal comparatives emerged from applying diagnostics used to adjudicate between RCAs and DAs:

2 Yori-comparatives with multiple remnants are derived from clausal sources via RCA. When the remnant is a single DP remnant, Bhatt \& Takahashi (2011) propose that the yori-comparative is derived via DA based on binding properties of the standard of comparison. RCA in constructions with a single DP is blocked by an economy constraint.

3 Both of these sentences can be rendered grammatical with a negu-comparative as shown in (i).

(i) a. Jonas perskaitè daugiau knygu negu Marija perskaitè.

John.NOM read.PST.3 more book.GEN than.CLAUSAL Maria.NOM read.PST.3

'John read more books than Maria.'

b. Šiandien Jonas perskaitė daugiau knygų negu vakar.

today John.NOM read.PST.3 more book.GEN than.CLAUSAL yesterday

'John read more books today than yesterday.' 
i. the standard of comparison and the associate are in the clause,

ii. the standard of comparison is invariably accusative case marked,

iii. the standard of comparison must be a DP.

All these empirical generalizations support a direct analysis of Lithuanian phrasal comparatives and not a reduced clause analysis. ${ }^{4}$ Despite the fact that the diagnostics overwhelmingly support a direct analysis, Grinsell (2012) develops a reduced clause analysis. His motivation for a clausal analysis is based on the fact that phrasal comparatives seem to exhibit island effects. Islands are assumed to be syntactic constraints that prevent extraction from certain syntactic configurations (e.g. Ross 1967; Chomsky 1995). Since under DAs, phrasal comparatives are base-generated mono-clausal structures, the presence of island effects would be unexpected. Since Merchant (2009), island effects have been used as an argument in favor of RCAs.

In this paper, I propose a direct analysis of Lithuanian phrasal comparatives under which the island violations emerge due to the movement of an associate at the LF. One consequence of this empirical discussion, which extends beyond the proper analysis of Lithuanian phrasal comparatives, concerns the use of island effects as a diagnostic used to adjudicate between RCAs and DAs originating in Merchant (2009). The use of this diagnostic has been extended into the description and analysis of phrasal comparatives of other languages (Grinsell 2012; Lindenbergh 2016). I suggest that the apparent island effects should not be considered as a decisive diagnostic, since they are compatible with RCAs and DAs contra claims in Merchant (2009).

\section{Empirical characterization of Lithuanian phrasal comparatives}

In this section, I discuss empirical generalizations about Lithuanian phrasal comparatives that are known in the literature. In subsection 2.2, I introduce a novel empirical generalization, which states that the associate must be the subject of the clause.

\subsection{Previously discussed empirical generalizations}

Three empirical generalizations about Lithuanian phrasal comparatives have been identified in Grinsell (2012).

First, phrasal comparatives are incompatible with measure phrases like du metrai 'two meters' as exemplified in (14a) (Grinsell 2012). The clausal comparative in (14b), on the other hand, is grammatical with the same measure phrase.
a. *Jonas aukštesnis už du metrus.
John.NOM taller.NOM than.PHRASAL two.ACC meter.ACC Intended meaning: 'John is taller than two meters.'
b. Jonas aukštesnis negu du metrai. John.NOM taller.NOM than.CLAUSAL two.NOM meter.NOM 'John is taller than two meters.'

Second, in Lithuanian nominal comparatives are formed with a comparative word daugiau 'more', which consists of two morphemes: daug 'a lot' and -iau '-er'. Phrasal comparatives in Lithuanian are ungrammatical if the subject of the sentence is preceded by daugiau 'more' as shown in (15a) (adapted from Grinsell 2012: 37). A clausal comparative, on the other hand, is grammatical, as shown in (15b). 
b. Daugiau student lanko Čikagos universitetą negu more student.GEN attend.PST.3 Chicago.GEN univeristy.ACC than.CLAUSAL Northwesterno.

Northwestern.GEN

'More students attend the University of Chicago than Northwestern.'

Third, Grinsell (2012) argues that phrasal comparatives exhibit island effects. Grinsell provides only one example of a phrasal comparative exhibiting the purported island effects, namely the example in (16).
*Daugiau žmoniu
kas
gyvena valstijoje, kurią
valdo
more people.GEN who.NOM live.PRs.3 state.LOC which.ACC govern.PRS.3
Obama,
už
Medvedeva.
Obama.NOM than.PHRASAL Medvedev.ACC
'More people live in the state that Obama governs than in the state that Medvedev governs.' (Grinsell 2012: 41)

The ungrammaticality of the example cannot be attributed conclusively to island sensitivity. The ungrammaticality is expected because, as discussed in Section 2, 'more DP subjects' are ungrammatical with phrasal comparatives. ${ }^{5}$ Consequently, the data provided in Grinsell (2012) does not constitute evidence for island effects.

To test a purported island sensitivity of phrasal comparatives, I constructed the minimal pair in (17), whereby the phrasal comparative does not violate any of the empirical generalizations discussed in this section. ${ }^{6}$

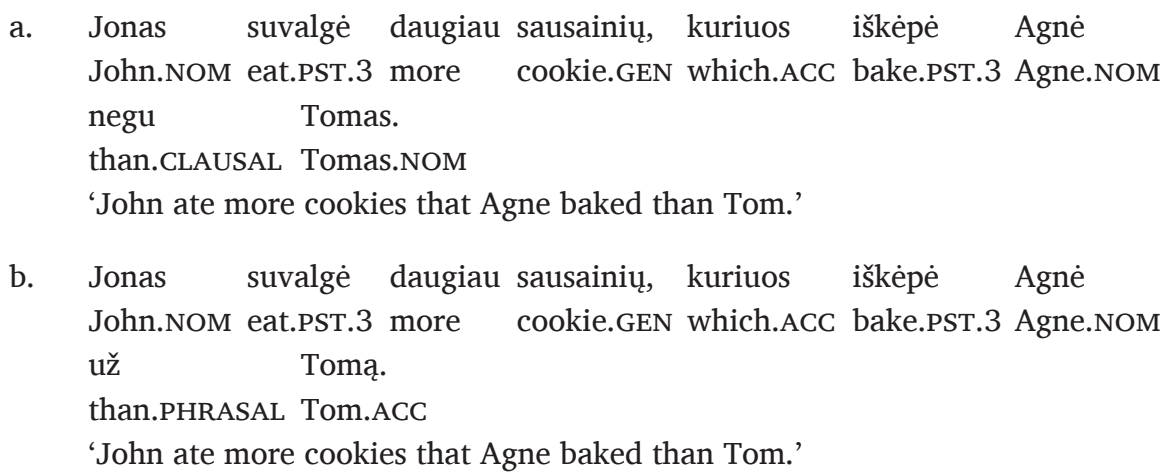

The clausal comparative in (17a) is ambiguous between two readings: Tomas 'Tom' can either be interpreted as the subject of the matrix verb suvalge 'ate' (leading to Reading 1 ) or the subject of the relative clause internal verb iškepe 'baked' (leading to Reading 2). ${ }^{7}$ The two readings and the syntactic structure associated with them is presented in (18).
a. $\quad$ Reading 1: John ate more cookies that Agne baked than Tom ate the cookies that Agne baked.
b. $\quad$ Reading 2: *John ate more cookies that Agne baked than he ate the cookies that Tom baked.

\footnotetext{
5 The sentence also contains some punctuation and vocabulary errors that could have influenced the acceptability of the sentence.

6 There is variability of acceptability of the comparatives in (17). Two out of three native speakers consulted
} found both sentences acceptable.

7 The most natural word order for these sentences as judged by three native speakers of Lithuanian is given in (i). In these examples, the DegP už Tomq and negu Tomas 'than Tom' is not sentence final. With this word order, the clausal comparative in (ia) is no longer ambiguous, as it can only have Reading 1.

(i) a. Jonas suvalgè daugiau negu Tomas sausainių, kuriuos iškèpè Agnè. John.NOM eat.PST.3 more than.CLAUSAL Tom.NOM cookie.GEN which.ACC bake.PST.3 Agne.NOM 'John ate more cookies that Agne baked than Tom (ate).'

b. Jonas suvalgè daugiau už Tomą sausainių, kuriuos iškèpè Agnè. John.NOM eat.PST.3 more than.PHRASAL Tom.ACC cookie.GEN which.ACC bake.PST.3 Agne.NOM 'John ate more cookies that Agne baked than Tom (ate).' 
The phrasal comparative in (17b) is grammatical, but in contrast to (17a), it only allows Reading 1, i.e. it is not ambiguous. The question is why Reading 2 is unavailable in (17b). Grinsell (2012) suggests that phrasal comparatives exhibit island effects. Based on the apparent island effects, Grinsell's (2012) concludes that since phrasal comparatives warrant a reduced clause analysis. In Section 3, I will show that island sensitivities are successfully captured in a direct analysis. Consequently, the unavailability of the relative clause internal reading cannot be viewed as evidence in favor of RCAs.

\subsection{Novel empirical generalization}

The novel empirical generalization about Lithuanian phrasal comparatives is that the associate must be the subject of the clause as shown in (19). ${ }^{8}$

In (19a), the associate is the subject of the clause Jonas 'John'. The comparison is between the number of doughnuts that were eaten by John and the number of doughnuts eaten by Tom. In the ungrammatical example in (19b), the associate is spurgu 'doughnuts', the direct object of the verb valgyti 'to eat'. The comparison is between the number of people eating doughnuts and the number of of people eating cookies.

$$
\begin{array}{llll}
\text { a. Jonas suvalge daugiau spurgu } & \text { už } & \text { Tomą. } \\
\text { John.NOM eat.PST.3 more doughnut.GEN than.PHRASAL Tom.ACC } \\
\text { 'John ate more doughnuts than Tom (ate).' } \\
\text { b. 'Jonas suvalgè daugiau spurgu } & \text { už } & \text { sausainius. } \\
\text { John.NOM eat.PST.3 more doughnut.GEN than.PHRASAL cookie.ACC } \\
\text { Intended meaning: 'John ate more doughnuts than cookies.' }
\end{array}
$$

One might wonder whether the correct empirical generalization for Lithuanian is that the associate cannot be a nominal that is part of 'more NP'. The sentence in (20) shows the privileged status of the subjects in phrasal comparatives more clearly. The phrasal comparative in (20) contains a ditransitive verb. Consequently, there are two nominals that are not part of 'more NP' and therefore could potentially serve as the associate. However, the sentence is not ambiguous in Lithuanian. Only the subject of the sentence Jonas 'John' can be interpreted to be the associate. The reading in which Marijai 'Maria', the indirect object of padovanojo 'gifted', is the associate does not arise in Lithuanian.

$$
\begin{aligned}
& \text { Jonas padovanojo Marijai daugiau dovanu už } \\
& \text { John.NOM gift.PST.3 Maria.DAT more present.GEN than.PHRASAL Tom.ACC } \\
& \text { 'John gave more presents to Maria than Tom (did).' } \\
& \text { \#'John gave more presents to Maria than (he did to) Tom.' }
\end{aligned}
$$

The example in (20) shows that the associate must be the subject of the sentence in Lithuanian.

In summary, this section discussed empirical generalizations that hold about Lithuanian phrasal comparatives as well as introduced a novel empirical generalization. An empirically adequate analysis needs to capture the following empirical generalizations about Lithuanian phrasal comparatives:

8 Lithuanian has dative experiencers, which in some languages behave as quirky subjects. Although dative experiencers are found in sentence-initial position, a position canonically reserved for subjects in Lithuanian, they are not syntactic subjects. Dative experiencers do not bind reflexives nor control agreement on the predicate with respect to person as shown in (i).

(i) ?Jonui patinka savo naujas švarkas.

John please.PRS.3 self.GEN new.NOM jacket.NOM

'John likes his new jacket.' (adapted from Holvoet 2013: 266))

In Lithuanian phrasal comparatives, the associate is the nominative case-marked DP and not the dative experiencer as shown in (ii), which is consistent with the novel empirical generalization.

(ii) Man spurgos patinka labiau už Joną.

I.DAT doughnut.NOM like.PRS. 3 more than John.ACC

'I like doughnuts more than I like John.'

\#'I like doughnuts more than John likes doughnuts.'

The binding pattern in experiencer constructions is changing according to Holvoet (2013), who suggests that in colloquial Lithuanian binding by dative experiencers is accepted by some speakers. 
i. they are ungrammatical with measure phrases (Grinsell (2012));

ii. they are ungrammatical if the subject of the sentence is preceded by daugiau 'more'

(Grinsell (2012));

iii. they exhibit island effects (Grinsell (2012));

iv. the associate must be the subject of the sentence.

\section{A direct analysis of Lithuanian phrasal comparatives}

In this section, I develop a direct analysis of Lithuanian phrasal comparatives (Hankamer 1973; Bhatt \& Takahashi 2007; 2011; Merchant 2012, among others). To illustrate basic assumptions of the analysis, consider the example in (21). The standard marker $u \check{z}$ 'than' is a preposition and the standard of comparison Toma 'Tom' is a DP argument of $u z$ 'than'. A partial syntactic derivation of the comparative is shown in (22) (assuming the AP analysis of comparatives following Bresnan 1973).

$$
\begin{aligned}
& \text { Jonas aukšt-esn-is }\left[_{\mathrm{PP}} \text { už } \quad\left[_{\mathrm{DP}} \text { Tomą.] }\right]\right. \\
& \text { John.NOM tall-ER-NOM than.PHRASAL Tom.ACC }
\end{aligned}
$$

'John is taller than Tom.'

(22)

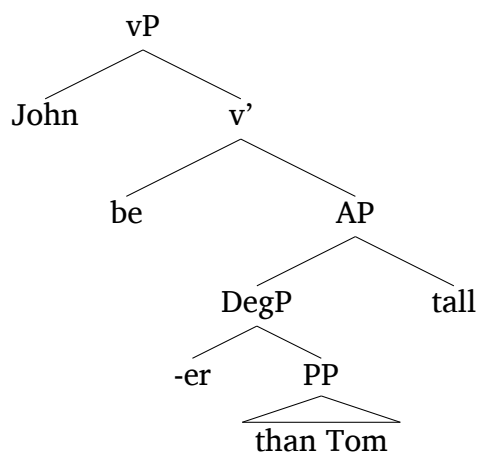

Following standard assumptions, I assume that gradable adjectives denote a function of type $\langle\mathrm{d},\langle\mathrm{e}, \mathrm{t}\rangle\rangle$, as in (23a). The morpheme -esn- 'er' marks the adjective in the comparative constructions. I assume that the comparative morpheme has the semantics of the comparative operator in (23b) (e.g. Heim (1985); Beck (2011); Bhatt \& Takahashi (2011)). The operator combines three arguments: an individual-denoting standard of comparison, a gradable predicate and an individual-denoting associate.

$$
\begin{array}{ll}
\text { a. } & \text { aukštas }=\lambda \mathrm{d} \lambda \mathrm{x} \cdot \operatorname{tall}(\mathrm{d})(\mathrm{x}) \\
\text { b. } & \llbracket-e s n-\rrbracket=\lambda \mathrm{x}_{\mathrm{e}} \lambda \mathrm{P}_{<\text {d,et }>} \lambda \mathrm{y}_{\mathrm{e}} \cdot \operatorname{MAX}(\lambda \mathrm{d} \cdot \mathrm{P}(\mathrm{d})(\mathrm{y}))>\operatorname{MAx}\left(\lambda \mathrm{d}^{\prime} \cdot \mathrm{P}\left(\mathrm{d}^{\prime}\right)(\mathrm{x})\right)
\end{array}
$$

Given these assumptions, the entire comparative in (21) is true if and only if the maximal degree of John's height exceeds the maximal degree of Tom's height, as shown in (24).

$$
\operatorname{MAX}(\lambda \mathrm{d} \cdot \operatorname{tall}(\mathrm{d})(\mathrm{j}))>\operatorname{MAx}\left(\lambda \mathrm{d}^{\prime} \cdot \operatorname{tall}\left(\mathrm{d}^{\prime}\right)(\mathrm{t})\right)
$$

Two points need to be explicated further about the proposed analysis.

First, in Lithuanian phrasal comparatives both the associate and the standard of comparison can be quantified phrases as shown in (25).
a. Jonas už
visus savo klasiokus
aukštesnis.
Jonas.NOM than.PHRASAL all.ACC self.GEN classmate.ACC.PL taller.NOM.SG 'Jonas is taller than all of his classmates.'
b. Visi Jono klasiokai už ji aukštesni. all.NOM John.GEN classmate.NOM.PL than.PHRASAL he.ACC taller.NOM.PL 'All John's classmates are taller than him.'

Since the comparative operator in (23b) expects two individual-denoting expressions but instead finds a quantified expression, a type mismatch arises. The type mismatch is resolved by QuantifierRaising the quantified expression. A schematic LF of the sentence in (25a) is given in (26). 


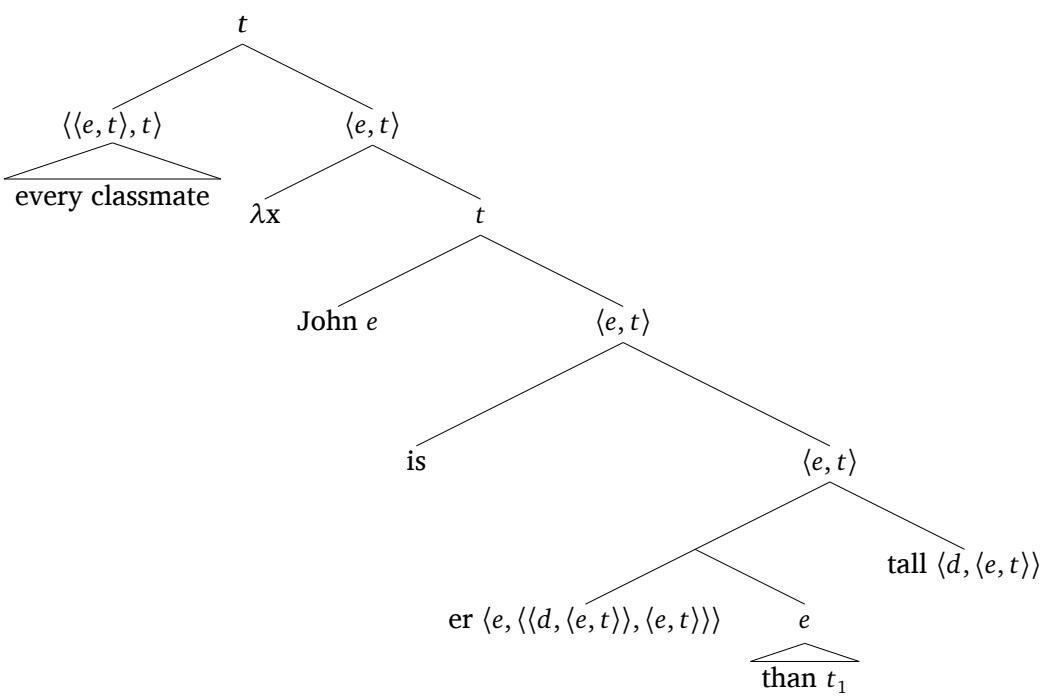

Second, the analysis of nominal comparatives relies on quantifier raising of the degree phrase. The movement of DegP is motivated by a type clash. The degree head expects the second argument to be a degree predicate. There is however, no degree predicate on the surface. I assume that daugiau 'more' in nominal comparatives is composed of determiner daug 'a lot' and the comparative morpheme -iau (cf. Bresnan (1973); Hackl (2000), a.o. for the view that English more is composed out of many and the comparative morpheme -er). I assume Hackl's semantics for the generalized quantifier daug 'many'. Following Bhatt \& Takahashi (2011), I assume that nominal comparatives are derived via the mechanism of parasitic scope. ${ }^{9}$ Parasitic scope involves two subsequent applications of Quantifier Raising: the first one targets the associate and the second one targets the DegP. In the Lithuanian example in (27a), first the associate Jonas 'John' raises to a higher scope-taking position. The first movement of creates a predicate via lambda abstraction. The movement of DegP to a position below the raised associate (also known as tucking-in) turns the existing predicate into a degree predicate. Due to space considerations the QR of DP obuoliu 'apples' is not shown in the LF.

a. Jonas

suvalgè daugiau obuolių

už

Tomą.

John.NOM eat.PST.3 more apple.GEN than.PHRASAL Tom.ACC

'John ate more apples than Tom.'

b. LF:
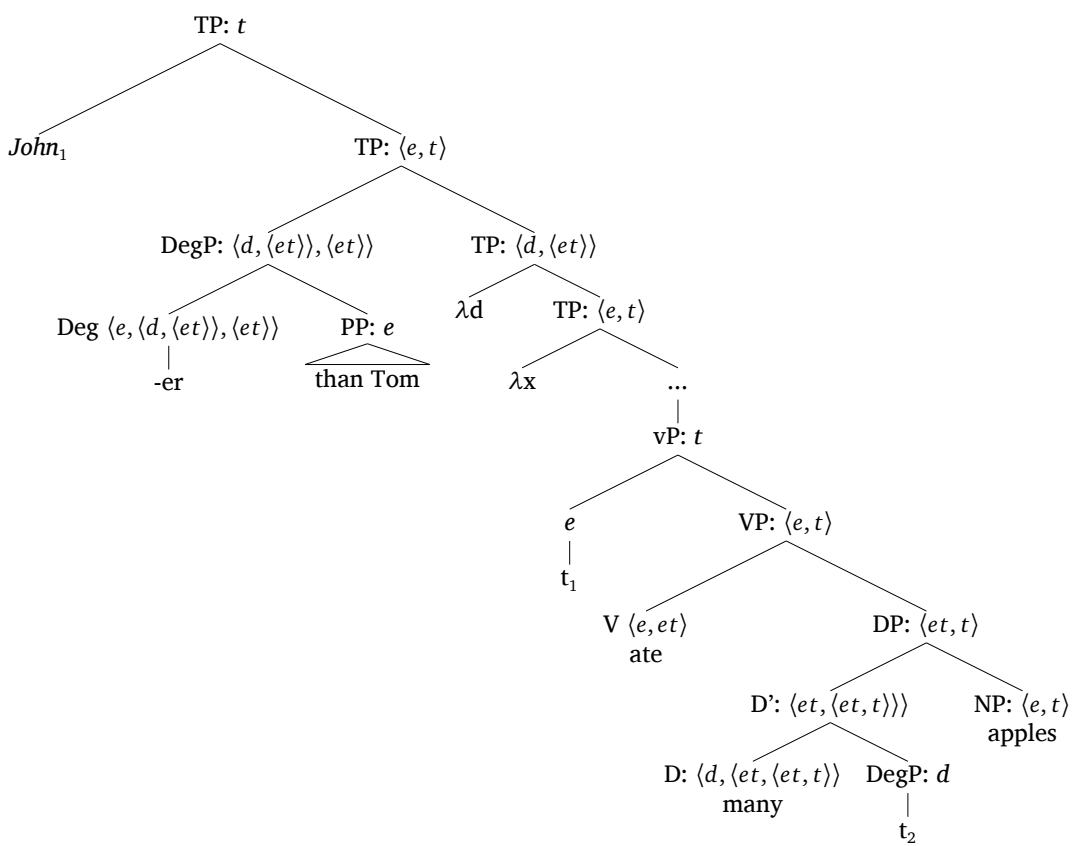

9 The mechanism whereby a movement targets a position created by a preceding operation has been proposed and motivated in the literature independently (e.g. Nissenbaum (2000), Barker (2007), Kennedy \& Stanley (2008)). 
Having introduced the basic tenets of the direct analysis argued for in this paper, I turn to the empirical generalizations. First, as already discussed in Section 1, some of the empirical generalizations about Lithuanian phrasal comparatives straightforwardly fall out from the direct analysis. The fact that the standard of comparison must be a single DP is captured by the assumption that $u \check{z}$ 'than' is a preposition which selects for a DP argument. Invariant casemarking on the standard of comparison is captured by the assumption that the preposition $u \check{z}$ 'than' assigns accusative case to its argument. Lastly, the facts that the reflexives in the standard of comparison can be bound by the subject associate and that free pronouns cannot be bound by the subject associate are a direct consequence of the assumption that phrasal comparatives are mono-clausal. In the remainder of this section, I show how the direct analysis can also account for the four empirical generalizations laid out in Section 2.

First, measure phrases are incompatible with phrasal comparatives in Lithuanian. Measure phrases like 2 meters are ambiguous between two interpretations: a point on a scale $(\langle\mathrm{d}\rangle$, comparable to a temporal $2 o^{\prime}$ clock) or a predicate over scale intervals ( $\langle\mathrm{d}, \mathrm{t}\rangle$, comparable to 2 hours, see Schwarzschild (2005) for a detailed discussion). Since the comparative operator in (23b) expects the standard to denote an individual, measure phrases are predicted to be ungrammatical with phrasal comparatives.

Second, only the subject DP can be interpreted as the associate in Lithuanian phrasal comparatives. This restriction has not been observed in phrasal comparatives in other languages. For instance, the Japanese phrasal yori-comparative in (28a) is ambiguous between two readings, as both watashiwa 'I' or nekoo 'cats' can be interpreted as the associate (Matsui \& Kubota 2010: 126). This ambiguity is readily predicted by the parasitic scope mechanism: both watashiwa 'I' and nekoo 'cats' can be targeted by the first application of Quantifier Raising, resulting in two different LFs, (28b) and (28c) respectively.

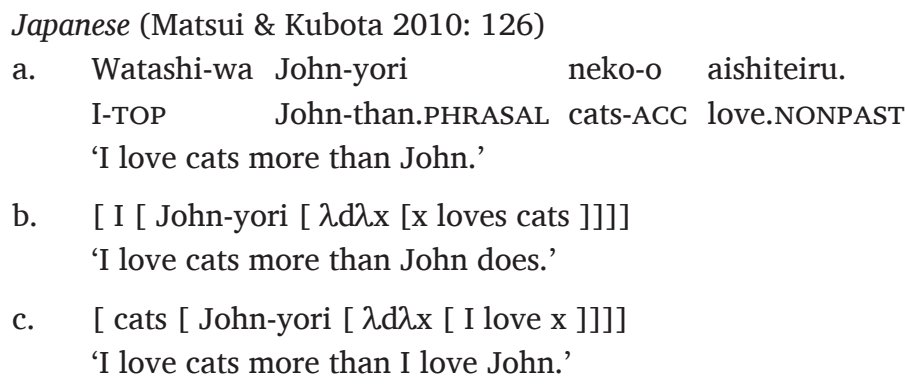

Since Lithuanian phrasal comparatives are not ambiguous, contrary to the Japanese example in (28a), I argue that Quantifier Raising is subject to an economy constraint in Lithuanian in the sense of Richards (1997) Shortest principle. ${ }^{10}$ The idea that Quantifier Raising is subject to an economy constraint is instantiated in Fox (1995) and Bruening (2001).

\section{Shortest (Richards (1997): 113)}

A pair P of elements $[\alpha, \beta]$ obeys Shortest iff there is no well-formed pair P' which can be created by substituting $\gamma$ for either $\alpha$ or $\beta$, and the set of nodes c-commanded by one element of P' and dominating the other is smaller than the set of nodes c-commanded by one element of $\mathrm{P}$ and dominating the other.

Following Heim \& Kratzer (1998: 210), I assume that the QR operation is available for all DPs, quantificational or not. Consequently, the subject DP is always in competition with other DPs. In (30a), both Jonas 'John' and Tomas 'Tom' could theoretically QR. The principle in (29), however, ensures that only the highest DP, i.e. the sentential subject, undergoes the process. Consequently, the associate can only be Jonas 'John' as shown in (30b). The LF in (30c) is ruled out as it violates Shortest. Jonas 'John' is structurally higher than Tomui 'Tom'. ${ }^{11}$

10 This economy constraint on movement is comparable to Chomsky's (1995) Minimal Link Condition and Rizzi's (1990) Relativized Minimality.

11 This analysis could also be amenable to an analysis in which QR is driven by feature attraction (e.g. Bruening 2001. I will leave it to future research to spell out the details of such an analysis and potential advantages of such an approach. 
b. [John [more than Agne [ $\lambda \mathrm{d} \lambda \mathrm{x}$ [x gave d-many presents to Tom] $]]$

c. * $\quad$ TTom [more than Agne $[\lambda d \lambda x$ [John gave d-many presents to $\mathrm{x}]]]]]$

As pointed out by an anonymous reviewer, adopting Shortest makes a more general prediction about quantifier scope in Lithuanian, namely it predicts that the language is scopally rigid. This prediction is borne out. In the Lithuanian example in (31) that contains two quantified expressions, only the surface scope reading is available as judged by three native speakers consulted. The fact that the surface scope reading is available, whereas the inverse scope reading is not available indicates that quantifier raising is not freely available in Lithuanian. ${ }^{12}$

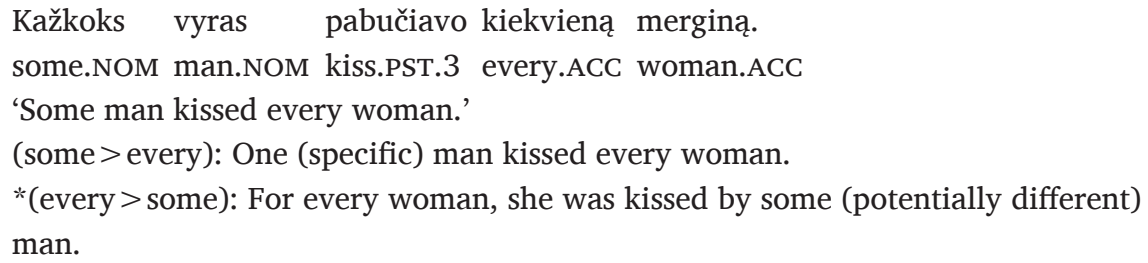

Shortest predicts that in a phrasal comparative that contains a relative clause, only the subject of the matrix clause can function as the associate. This prediction is borne out as shown in (32a). Only Jonas ‘John' can undergo Quantifier Raising, as shown in (32b). By contrast, the structure in (32c), in which Agne 'Agne' undergoes Quantifier Raising is ruled out as it violates Shortest.

$$
\begin{aligned}
& \text { a. Jonas suvalgè daugiau už Tomą sausainių, } \\
& \text { John.NOM eat.PST.3 more than.PHRASAL Tom.ACC biscuit.GEN } \\
& \text { kuriuos iškèpè Agnè. } \\
& \text { which.ACc bake.PST.3 Agne.NOM } \\
& \text { 'John ate more biscuits that Agne baked than Tom.' }
\end{aligned}
$$

The relative clause internal reading in (32c) is also be ruled out independently provided that Quantifier Raising is subject to island constraints (see e.g. Tanaka 2015 for experimental evidence). The associate Agne would have to QR out of a relative clause resulting in an islandviolation. The apparent island-effects thus can be explained in a direct analysis. The movement of the associate cannot be island-violating. This analysis differs from the analysis presented in Grinsell (2012). The latter assumes that the island-violation arises due to the island-violating movement of the remnant, in this example Toma. Grinsell's analysis is discussed in more detail in Section 4.

Lastly, Lithuanian phrasal comparatives are ungrammatical with 'more DP subjects'. In Lithuanian, 'more DP subjects' are ruled out by Shortest since the subject DP žmoniu 'people' intervenes and thus rules out the QR of vyna 'wine' as shown in (33b).

$$
\begin{aligned}
& \text { a. *Daugiau žmonių gerè vyną už alų. } \\
& \text { more people.GEN drink.PST.3 wine.ACC than.PHRASAL beer.ACC } \\
& \text { 'More people drank wine than beer.' } \\
& \text { b. [wine [more than beer }[\lambda \mathrm{d} \lambda \mathrm{x} \text { [d-many people drank } \mathrm{x}]]]]
\end{aligned}
$$

Lithuanian shares the 'more DP subjects' restriction with some other Balto-Slavic languages, for instance, Bulgarian as shown in the minimal pair in (34) (Pancheva 2009: 2). As in Lithuanian, the subject of a phrasal comparative cannot be preceded by a comparative word poveče 'more' in Bulgarian, as shown in (34a). The sentence can be rendered grammatical with a clausal otkolkoto-comparative as shown in (34b).

12 Russian, a related Balto-Slavic language, has been argued to be scopally rigid as well by Ionin (2001), though this characterization was challenged in Antonyuk 2015. Further research is necessary to determine whether inverse scope might become available under certain pragmatic conditions or prosody in Lithuanian. 
a. *Poveče turisti posetixa Sofia ot Varna.

more tourists visited Sofia than.PHRASAL Varna

'More tourists visited Sofia than Varna.'

b. Poveče turisti posetixa Sofia otkolkoto Varna. more tourists visited Sofia than.CLAUSAL Varna 'More tourists visited Sofia than Varna.' $\quad$ (Pancheva 2009: 2)

Lechner (2017) proposes that certain phrasal comparatives in the Slavic languages are subject to the Parasitic Scope Generalization, as defined in (35).

\section{Parasitic Scope Generalization (PSG)}

In environments where movement of $\alpha$ provides the semantic context for type driven movement of $\beta$, the base position of $\alpha$ c-commands the base position of $\beta$.

A DegP can only move if the associate in its base position c-commands the DegP. The Bulgarian phrasal comparative in (34a) is predicted to be ungrammatical, since the associate Sofia 'Sofia' does not c-command the DegP poveče ot Varna 'more than Varna' as shown in (36).

$$
\text { [Sofia [more than Varna }[\lambda \mathrm{d} \lambda \mathrm{x} \text { [d-many tourists visited } \mathrm{x}]]]]
$$

It is possible that PSG is operational in Lithuanian phrasal comparatives just as it is in many Slavic languages, thus restricting the parasitic scope mechanism even further. The sentence in (33a) could also potentially be ruled out by PSG. Since the associate DP vynu 'wine' in its base position does not c-command the DegP daugiau už alu 'more than beer' as shown in (33b). However, it is not possible to test whether PSG is operational in Lithuanian phrasal comparatives. For instance, PSG would predict that the sentence in (37) is ambiguous between subject associate and indirect object associate reading. However, Shortest rules out the indirect object associate reading. Shortest thus only allows a subset of sentences that do not violate PSG. Further research is needed to determine whether there is independent evidence to assume PSG is operational in Lithuanian.

$$
\begin{array}{llllll}
\text { Jonas } & \text { nusiuntè } & \text { Agnei } & \text { daugiau laiškų } & \text { už } & \text { Tomą. } \\
\text { John.NOM } & \text { send.PST.3 Agne.DAT more letters.GEN than.PHRASAL Tom.ACC } \\
\text { 'John sent more letters to Agne than Tom (did). } &
\end{array}
$$

By virtue of adopting the direct analysis of phrasal comparatives and enriching it with one constraint on Quantifier Raising (Shortest), we can account for all empirical generalizations about Lithuanian phrasal comparatives that we set out to capture in Section 2.

\section{Grinsell's (2012) reduced clause analysis}

Standard diagnostics applied to Lithuanian phrasal comparatives motivates a direct analysis, yet the first analysis of Lithuanian phrasal comparatives in Grinsell (2012) argues them to be underlyingly clausal. The aim of this section is two-fold: i) to introduce Grinsell's reduced clause analysis of Lithuanian phrasal comparatives; ii) to critically assess the analysis in terms of its empirical coverage.

\subsection{Reduced clause analysis of Lithuanian phrasal comparatives}

Grinsell (2012) adopts the reduced clause analysis originally proposed in Merchant (2009) for phrasal comparatives in Modern Greek. Under this analysis, the standard of comparison is a clause, as shown in (38b) for the phrasal comparative in (38a). The remnant Toma 'Tom' moves to a clause external position, while the clause itself undergoes TP-ellipsis (ellipsis site indicated by the angled brackets). The remnant Toma 'Tom' moves cyclically to specPP via specFP, while the standard marker $u \check{z}$ 'than' moves from $\mathrm{P}$ to $p$.

a. Jonas aukštesnis už Tomą <yra aukštas. >

John.NOM taller.NOM than.PHRASAL Tom.ACC be.PRS.3 tall.NOM

'John is taller than Tom.' 
b. Partial derivation:

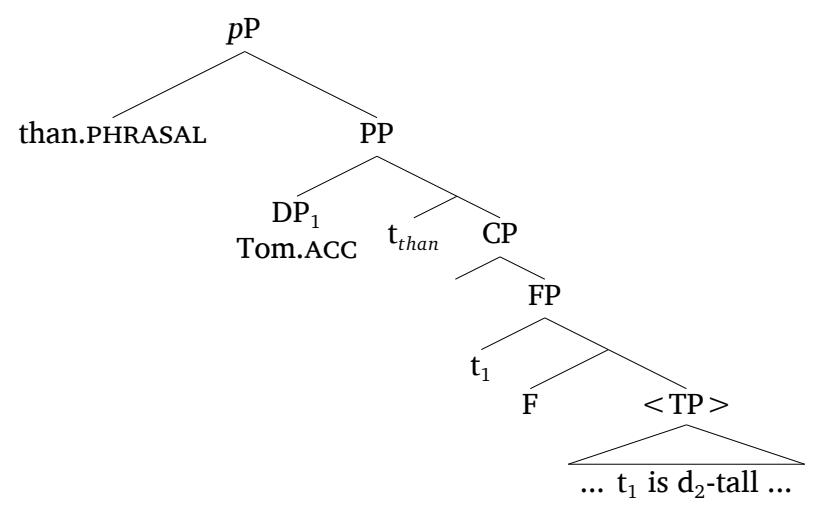

Following Merchant (2009), Grinsell assumes that island effects arise from a prohibition against unelided island-violating traces. More specifically, illicit traces are assumed to be PFuninterpretable. The phrasal comparative in (39a) is predicted to be ungrammatical under this analysis because the remnant Medvedeva 'Medvedev' leaves an unelided island-violating trace in specFP as shown in (39b).
a. *Daugiau žmoniu
gyvena valstybeje, kurią
valdo
more people.GEN live.PRS.3 state.LOC which.ACC govern.PRS.3
Obama, už Medvedevą.
Obama.NOM than.PHRASAL Medvedev.ACC
'More people live in the state that Obama governs than in the state that Medvedev governs.' (adapted from Grinsell 2012: 41)

b. Partial derivation:

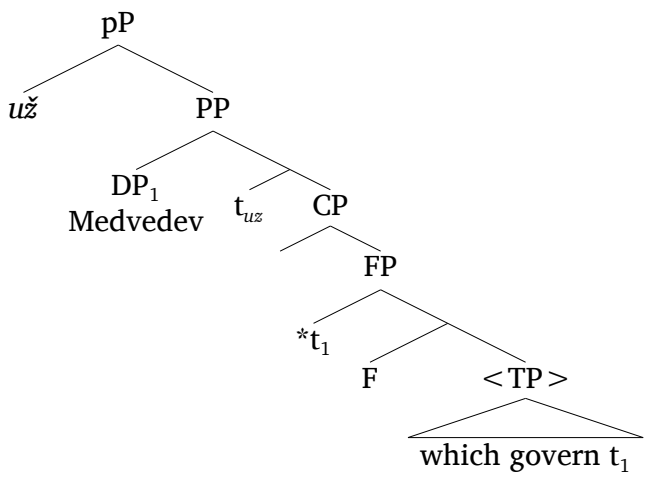

Grinsell's reduced clause analysis thus captures the ungrammaticality of (39a), attributing the ungrammaticality to island effects (though recall that this particular sentence is also ruled out by 'more DP subject' constraint).

Under this analysis, both phrasal and clausal comparatives are bi-clausal, i.e. the standard of comparison is a clause. As shown in (40), a clausal comparative is grammatical. It is thus in need of explanation as to why clausal comparatives do not exhibit island effects.

$$
\begin{array}{llllll}
\text { Daugiau } & \text { žmonių kas } & \text { gyvena valstijoje, kurią } & \text { valdo } \\
\text { more } & \text { people.GEN who.NOM live.PRS.3 } & \text { state.LOC } & \text { which.ACC } & \text { govern.PRS.3 } \\
\text { Obama, } & \text { negu } & \multicolumn{2}{c}{\text { Medvedevas. }} &
\end{array}
$$

Obama.NOM than.CLAUSAL Medvedev.NOM

'More people live in the state that Obama governs than in the state that Medvedev governs.' (Grinsell 2012: 41)

Following Merchant (2009), Grinsell (2012) suggests that the final landing site of the remnant is different in phrasal and clausal comparatives. In clausal comparatives, the final landing site is specFP. Grinsell (2012) argues that the clausal standard marker negu 'than' is morphologically complex as opposed to the morphologically simplex phrasal standard marker $u$ ž 'than'. Historically, negu 'than' consists of two morphemes: $n e$ 'NEG' and gu a clitic (Bender (1921) as cited in Grinsell (2012)). Grinsell suggests that the two morphemes occupy distinct positions in the syntax. Crucially, the negation morpheme occupies specPP. The remnant Medvedeva 
'Medvedev' therefore cannot move higher than specFP in the clausal comparative in (40), which is analyzed in (41). Since the remnant occupies specFP, there is no island-violating trace as shown in (41), which captures the absence of island effects in clausal comparatives.
Clausal comparative adopted from Grinsell (2012: 46):

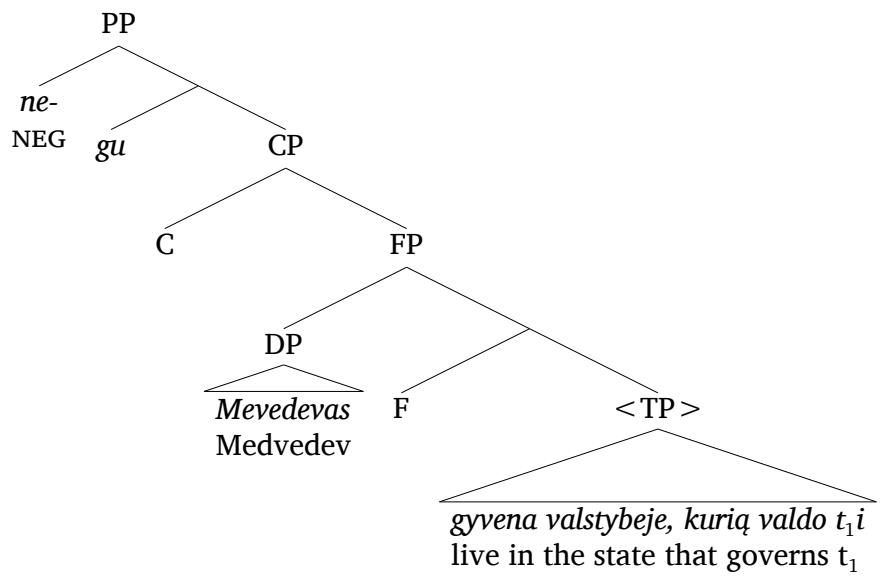

Grinsell's analysis thus is equipped to capture the purported island effects in phrasal comparatives as well as explain the lack of island effects in clausal comparatives. Grinsell's analysis, however, faces a number of challenges that are discussed in subsection 4.2.

\subsection{Critique of Grinsell (2012)}

In this subsection, I will discuss the stipulations Grinsell makes to account for the seeming local relationship between the associate and the remnant as revealed by the diagnostic tests in Section 1. I will then show that the reduced clause analysis does not account for the empirical generalizations discussed in Section 2 with the exception of the purported island effects.

First, to account for case-invariability on the remnant, Grinsell following Merchant (2009), posits an accusative case feature on $p$. To account for the fact that only a DP can serve as a remnant, Grinsell suggests that this fact can be captured either by assuming that only a DP can enter into an Agree relation with the case feature on $p$, or DP raising is triggered by a strong category feature (both Merchant (2009) and Grinsell (2012) remain agnostic with regard to the two options).

Grinsell's reduced clause analysis thus can successfully derive the local effects between the preposition $u \check{z}$ 'than' and the remnant as well as between the matrix clause and the remnant. The analysis is, however, less successful in accounting for the empirical generalizations discussed in Section 2.

First, Grinsell (2012)'s analysis does not capture the fact that Lithuanian phrasal comparatives are ungrammatical with measure phrases. The phrasal comparative with a measure phrase $d u$ metrai 'two meters' in (42) is incorrectly predicted to be grammatical in Lithuanian. The remnant is an accusative case-marked DP which is not contained within an island, i.e. it does not leave an illicit island violating trace, consequently it should be grammatical.

$$
\begin{aligned}
& \text { *Jonas auštesnis už } \quad \text { du metrus < aukštas>. } \\
& \text { John.NOM taller.NOM than.PHRASAL two.ACC meter.ACC tall } \\
& \text { 'John is taller than two meters.' }
\end{aligned}
$$

Second, Grinsell (2012)'s analysis cannot capture the 'more DP subject' restriction. Grinsell (2012: 46) suggests in passing that the restriction can be analyzed 'as the result of an unelided island-violating trace'. However, the 'more DP subject' restriction cannot be reduced to a prohibition against unelided island-violating traces. In (43), the remnant Balta Drobule 'White Cloth' does not originate in an island. Under his reduced clause analysis, the phrasal comparative in (43) would be incorrectly predicted to be grammatical in Lithuanian.

$$
\begin{aligned}
& \text { *Daugiau žmonių perskaitė Altorių Šešèly už Baltą Drobulę. } \\
& \text { more people.GEN read.PST. } 3 \text { altar.GEN shadow.LOC than white.ACC cloth.ACC } \\
& \text { 'More people read the novel Altoriu Sesely than Balta Drobule.' }
\end{aligned}
$$


In this section, I have shown that the reduced clause analysis developed in Grinsell (2012) needs to make additional stipulation to account for the empirical generalizations that come for free from the direct analysis Most importantly, however, I have shown that the analysis does not account for the empirical generalizations discussed in Section 2.

\section{Conclusions}

Phrasal comparatives can be analyzed as bi-clausal (RCAs) or mono-clausal structures (DAs). Both analyses are attested cross-linguistically (see e.g. Bhatt \& Takahashi 2011).

This paper argues that phrasal comparatives in Lithuanian are mono-clausal. In Section 1, I show that a direct analysis receives support from the standard diagnostics used to adjudicate between RCAs and DAs: binding, case-marking on the standard of the comparison and the single remnant restriction. Under the direct analysis proposed in this paper the standard of comparison is a DP. Phrasal comparatives are interpreted via the Parasitic Scope Mechanism, which is subject to one economy constraint: Shortest (Richards 1997). In Section 3, I show that the direct analysis advocated for in this paper captures the whole range of empirical generalizations about Lithuanian phrasal comparatives. Under this analysis, island effects emerge when the associate quantifier raises. To further promote the direct analysis of Lithuanian phrasal comparatives, in Section 4.2, I demonstrate that Grinsell's reduced clause analysis faces serious challenges with regard to its empirical coverage.

Thus far the paper has focused on the proper analysis of Lithuanian phrasal comparatives, however, the empirical discussion has implications for the analyses of phrasal comparatives cross-linguistically. Namely, it calls into question the status of island effects as a deciding diagnostic adjudicating RCAs and DAs.

Island effects were first used as an argument in favor of a reduced clause analysis in Merchant (2009). Merchant (2009) shows that Modern Greek phrasal comparatives exhibit phrasal properties: they license binding of clause-bound reflexive ton eafto tu 'himself' and the standard of comparison is invariably accusative-case marked as shown in (44a) and (44b) respectively.

$$
\begin{aligned}
& \text { Modern Greek (Merchant 2009: 138, 136) } \\
& \text { a. Kanenas Sen ine psiloteros apo ton eafto tu. } \\
& \text { n-person NEG is taller than.PHRASAL the self his } \\
& \text { 'No one is taller than himself.' } \\
& \text { b. I Maria pezi kiӨara kalitera apo ton Gianni. } \\
& \text { the Maria.NOM plays guitar better than.PHRASAL the Giannis.ACC } \\
& \text { 'Maria plays the guitar better than Giannis.' }
\end{aligned}
$$

The data presented in (44) thus warrants a direct analysis of Modern Greek phrasal comparatives. However, phrasal comparatives exhibit island sensitivities as shown in (45).

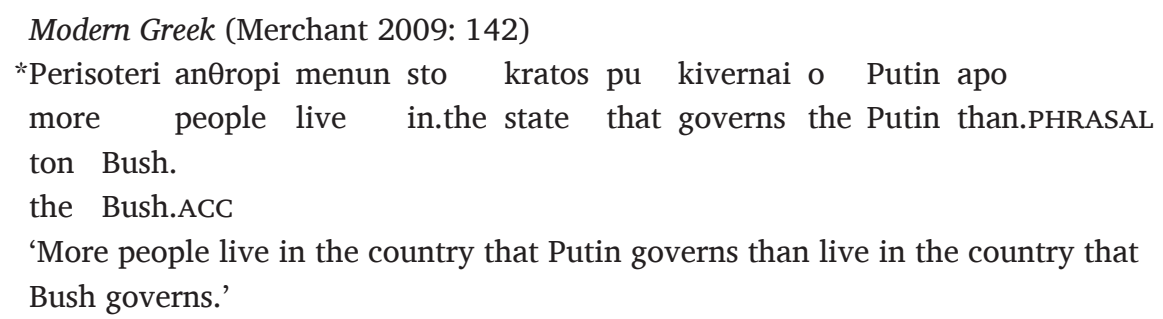

Merchant interprets the data in (45) as an argument in favor of RCAs. This argument rests on two assumptions: i) there are certain syntactic configurations extraction from which is degraded or ungrammatical ${ }^{13}$ and ii) the remnant moves from its base-generated position to a clause external position to escape ellipsis. While assuming a full-fledged clausal structure for the standard of comparison is at odds with other data in (44), Merchant takes the presence of island effects to be the deciding factor. Consequently, he proposes a reduced clause analysis for Modern Greek

13 Whether the extraction is ruled out by some syntactic constraint on dependencies (e.g. subjacency, relativized minimality, illicit PF representations, etc.) as assumed in the mainstream generativist syntax or whether it is ruled out by some processing constraints (e.g. Hofmeister \& Sag (2010), Chaves \& Dery (2019), among others), has no bearing on the current argument, since in both views the same clausal structures are assumed. 
phrasal comparatives. The same line of reasoning has been applied for phrasal comparatives in other languages (e.g. Dutch Lindenbergh (2016) and Lithuanian Grinsell (2012)).

This paper has shown that the data that has been interpreted as evidence for island effects can be captured without making reference to underlying syntactic structures. Island violations arise due to the movement of the associate as LF movement cannot be island-violating. Our conclusion is that such data can be consistent with both direct and reduced clause analyses and should not be a priori interpreted as irrefutable evidence for RCAs. This raises the question about a proper analysis of Modern Greek apo-comparatives, especially since the Modern Greek phrasal comparatives behave similarly to Lithuanian phrasal comparatives in terms of casemarking on the associate and binding. That being said, it is beyond the scope of this paper to explore an alternative direct analysis of Modern Greek phrasal comparatives and its potential advantages.

Finally, this work is of typological interest as it adds a new empirical generalization into the discussion of variation in phrasal comparatives. Namely in Lithuanian only the subject of the clause can function as the associate. Bulgarian, a Balto-Slavic language, in which the 'more DP subject' constraint is active as it is in Lithuanian, allows non-subjects to be interpreted as associates as shown in (46).

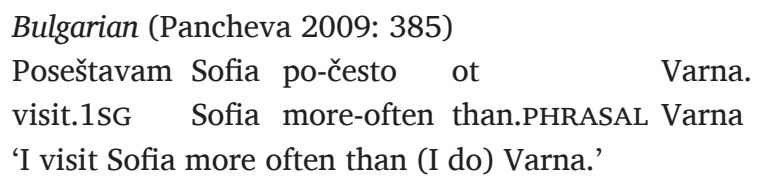

The same holds for Modern Greek apo-comparatives as shown in (47), where the associate is the direct object anglika 'English'.

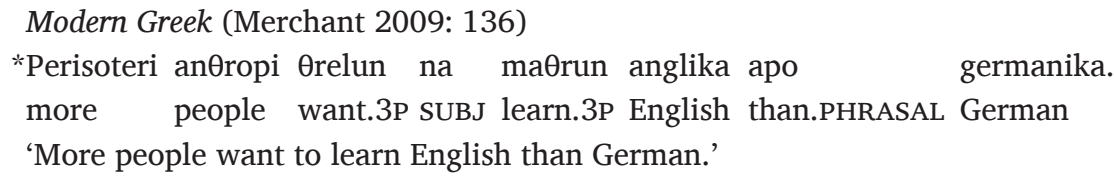

Lithuanian thus seems to be the only language known to exhibit the requirement that the associate is the subject of the sentence. Whether any other language exhibits this empirical generalization requires a thorough description of phrasal comparatives cross-linguistically and therefore is left for future work.

\section{Abbreviations}

$1=$ first person, $3=$ third person, $\mathrm{ACC}=$ accusative, $\mathrm{DAT}=$ dative, $\mathrm{GEN}=$ genitive, $\mathrm{LOC}=$ locative, $\mathrm{NOM}=$ nominative, $\mathrm{PL}=$ plural, $\mathrm{PRS}=$ present, $\mathrm{PST}=$ past, $\mathrm{SG}=$ singular, $\mathrm{SUBJ}=$ subjunctive

\section{Acknowledgements}

I am very grateful to Judith Tonhauser, Peter Culicover and Bob Levine for critical feedback throughout the course of this paper. For helpful comments I also thank the anonymous reviewers and the participants of the syntax reading group at the The Ohio State University.

\section{Competing interests}

The author has no competing interests to declare.

\section{Author affiliation}

Elena Vaikšnoraitė (D) orcid.org/0000-0001-7214-7982

The Ohio State University/University of Stuttgart, Stuttgart, DE 


\section{References}

Antonyuk, Svitlana. 2015. Quantifier scope and scope freezing in Russian. Stony Brook, NY: Stony Brook University dissertation.

Barker, Chris. 2007. Parasitic scope. Linguistics and Philosophy 30(4). 407-444. DOI: https://doi. org/10.1007/s10988-007-9021-y

Beck, Sigrid. 2011. Comparison constructions. In Claudia Maienborn, Klaus von Heusinger \& Paul Portner (eds.), Semantics: An international handbook of natural language meaning 2. 1341-1389. Berlin: Mouton de Gruyter.

Bender, Harold Herman. 1921. A Lithuanian etymological index. Princeton, NJ: Princeton University Press.

Bhatt, Rajesh \& Shoichi Takahashi. 2007. Direct comparisons: Resurrecting the direct analysis of phrasal comparatives. Semantics and Linguistic Theory (SALT) 17. 19-36. DOI: https://doi.org/10.3765/salt. v17i0.2958

Bhatt, Rajesh \& Shoichi Takahashi. 2011. Reduced and unreduced phrasal comparatives. Natural Language and Linguistic Theory 29(3). 581-620. DOI: https://doi.org/10.1007/s11049-011-9137-1

Bresnan, Joan W. 1973. Syntax of the comparative clause construction in English. Linguistic Inquiry 4(3). 275-343.

Bruening, Benjamin. 2001. QR obeys superiority: Frozen scope and ACD. Linguistic Inquiry 32(2). 233273. DOI: $h$ ttps://doi.org/10.1162/00243890152001762

Chaves, Rui P. \& Jeruen E. Dery. 2019. Frequency effects in subject islands. Journal of Linguistics 55(3). 475-521. DOI: $h$ ttps://doi.org/10.1017/S0022226718000294

Chomsky, Noam. 1995. The minimalist program. Cambridge, MA: MIT Press.

Fox, Danny. 1995. Economy and scope. Natural Language Semantics 3(3). 283-341. DOI: https://doi. org/10.1007/BF01248820

Gillon, Carrie \& Solveiga Armoskaite. 2015. The illusion of the NP/DP divide: Evidence from Lithuanian. Linguistic Variation 15(1). 69-115. DOI: https://doi.org/10.1075/lv.15.1.03gil

Grinsell, Timothy W. 2012. Phrasal and clausal comparatives in Lithuanian. Formal Approaches to Slavic Linguistics (FASL), 33-49.

Hackl, Martin. 2000. Comparative quantifiers. Cambridge, MA: Massachusetts Institute of Technology dissertation. DOI: https://doi.org/1721.1/8765

Hankamer, Jorge. 1973. Why there are two than's in English. Chicago Linguistics Society (CLS) 9. 179-191.

Heim, Irene. 1985. Notes on comparatives and related matters. Ms. University of Texas.

Heim, Irene \& Angelika Kratzer. 1998. Semantics in generative grammar. Oxford: Blackwell.

Hofmeister, Philip \& Ivan A. Sag. 2010. Cognitive constraints and island effects. Language 86(2). 366. DOI: https://doi.org/10.1353/lan.0.0223

Holvoet, Alex. 2013. Obliqueness, quasi-subjects and transitivity in Baltic and Slavonic. In Ilja A. Seržant \& Leonid Kulikov (eds.), The diachronic typology of non-canonical subjects, 257-282. Amsterdam, PA: John Benjamins Publishing Company. DOI: https://doi.org/10.1075/slcs.140.12hol

Ionin, Tania. 2001. The one girl who was kissed by every boy: Scope, scrambling and discourse function in Russian. ConSole X, 65-80.

Kennedy, Christopher \& Jason Stanley. 2008. What an average semantics needs. Semantics and Linguistic Theory (SALT) 18. 465-482. DOI: https://doi.org/10.3765/salt.v18i0.2513

Lechner, Winfried. 2001. Reduced and phrasal comparatives. Natural Language \& Linguistic Theory 19(4). 683-735. DOI: https://doi.org/10.1023/A:1013378908052

Lechner, Winfried. 2004. Ellipsis in comparatives. Berlin: Walter de Gruyter. DOI: https://doi. org/10.1515/9783110197402

Lechner, Winfried. 2017. Phrasal comparatives and parasitic scope. In Clemens Mayr \& Edwin Williams (eds.), Festschrift für Martin Prinzhorn, 181-192. Vienna: Department of Linguistics, University of Vienna.

Lindenbergh, Charlotte. 2016. Phrasal and clausal comparatives in Dutch. Linguistics in the Netherlands 33(1). 70-88. DOI: https://doi.org/10.1075/avt.33.06lin

Matsui, Ai \& Yusuke Kubota. 2010. Comparatives and contrastiveness: Semantics and pragmatics of Japanese hoo comparatives. Formal Approaches to Japanese Linguistics 5. 126-139.

Merchant, Jason. 2009. Phrasal and clasal comparatives in Greek and the abstractness of syntax. Journal of Greek linguistics 9(1). 134-164. DOI: https://doi.org/10.1163/156658409X12500896406005

Merchant, Jason. 2012. The two phrasal comparatives of Greek. Ms. University of Chicago.

Nissenbaum, Jonathan W. 2000. Investigations of covert phrase movement. Cambridge, MA: Massachusetts Institute of Technology dissertation. DOI: https://doi.org/1721.1/8842

Pancheva, Roumyana. 2006. Phrasal and clausal comparatives in Slavic. Formal Approaches to Slavic Linguistics (FASL) 14. 236-257.

Pancheva, Roumyana. 2009. More students attended FASL than CONSOLE. Formal Approaches to Slavic Linguistics (FASL) 18. 382-399. 
Richards, Norvin Waldemar. 1997. What moves where when in which languages? Cambridge, MA: Massachusetts Institute of Technology dissertation. DOI: https://doi.org/1721.1/10236

Rizzi, Luigi. 1990. Relativized minimality. Cambridge, MA: MIT Press.

Ross, John Robert. 1967. Constraints on variables in syntax. Cambridge, MA: Massachusetts Institute of Technology dissertation. DOI: https://doi.org/1721.1/15166

Schwarzschild, Roger. 2005. Measure phrases as modifiers of adjectives. Recherches Linguistiques de Vincennes 34. 207-228. DOI: https://doi.org/10.4000/rlv.1401

Tanaka, Misako. 2015. Asymmetries in long-distance QR. Berkeley Linguistics Society 41. 493-501. DOI: https://doi.org/10.20354/B4414110000
Glossa: a journal of general linguistics

DOI: 10.5334 /gjgl.935
TO CITE THIS ARTICLE:

Vaikšnoraitè, Elena. 2021. A direct analysis of Lithuanian phrasal comparatives. Glossa: a journal of general linguistics 6(1): 65. 1-18. DOI: https:// doi.org/10.5334/gjgl.935

Submitted: 06 March 2019 Accepted: 09 November 2020 Published: 11 May 2021

COPYRIGHT:

(c) 2021 The Author(s). This is an open-access article distributed under the terms of the Creative Commons Attribution 4.0 International License (CC-BY 4.0), which permits unrestricted use, distribution, and reproduction in any medium, provided the original author and source are credited. See http:// creativecommons.org/ licenses/by/4.0/.

Glossa: a journal of general linguistics is a peer-reviewed open access journal published by Ubiquity Press. 